\title{
MODERNIZATION OF NURSING EDUCATION AND NURSE' IT COMPETENCE
}

\author{
Danguolė Šakalyte \\ Utena College, Lithuania
}

\begin{abstract}
The use of technology in nursing is not new; in fact, nurses have become proficient in utilizing and adapting complex technology into caring nursing practice. Since nurses are the largest group of health care providers, discipline-specific competencies in the use of ICT and other technologies are imperative. This realization has catalyzed the steady development of nursing informatics. Nursing schools demonstrate use of recognized approaches to teaching and learning in their programs, including, but not limited to, adult education, selfdirected learning, e-learning and clinical simulation. The article' aims are to review modernization of nursing education and to assess nurse' IT competence according to professional skills comparing groups with different educational background and work experience.
\end{abstract}

Keywords: Competence, Education, Information Technology, Nursing.

\section{Introduction}

The nursing is one of many rapidly developing fields of human activity, in which working environment is strongly influenced by progress of information technologies and the development of computerization. The modern nursing system effective working and the availability, medical and nursing information processing are unthinkable without the computer and the Internet. Information technology, Internet and WWW is an important factor in the nursing education and clinical practice. The nursing accepts an active position in the use of information technology in the nursing degree programs and in the practical field. Coming of these technologies reflects peer relationships between nursing educators, nursing practitioners, technicians, students and technology as such.

The use of technology in nursing is not new, in fact, nurses have become proficient in utilizing and adapting complex technology into caring nursing practice for decades, at least since the time of F. Nightingale in the United Kingdom and even earlier, when J. Mance founded the first hospital in Montreal, Canada in 1642. Various forms of machinery such as ventilators and physiological monitors were first used in intensive and critical care settings, and are now currently used in adapted form in less acute areas, even in home care (Brief History of Nursing Informatics in Canada).

Nursing education is directed by guidelines of the World Health Organization, the European law and the laws of the members' states. Despite the growing convergence in educational systems and approach, at this time there no uniformity in the way nursing education is organized in Europe. Nursing schools 
demonstrate use of recognized approaches to teaching and learning in their programs, including, but not limited to, adult education, self-directed learning, e-learning and clinical simulation, as according Žydžiūnaitė (2002), nursing doesn't have the permanent, identifying mental model that defines and evaluates the quality of nursing. The author, based on studies conducted by other authors, argue that nurse competence involves more than the psychomotor skills, nursing standards specifies the level of nursing activity, in which the concrete tasks are expected to realize in the specific, specialized nursing field. By analyzing competencies of nursing degree programs students and practicing nurses, is noted that mastering skills, support by using IT, allows possibilities to realize complex nursing activities in the development of advanced nursing practice (Ševcovienè, 2010).

The article' aims are to review modernization of nursing education and to assess nurse' IT competence according to professional skills comparing groups with different educational background and work experience.

\section{Theoretical Framework}

Historically, competence was related to the nature of the nurse's role as a practical bedside nurse. This system of competence presumed a clearly defined purpose, the production of the bedside nurse, whose primary function was to care for the sick person. By the second half of the twentieth century, the practical nursing care of patients was linked to and synthesised with a theoretical knowledge base, linking underlying theory to the clinical practice of patient care. As argued Bielinienè (2007), nursing practice is focused to the health and to the human and based on a systematic problem-solving method by a worldwide. Nurses must be "generalist", mastering extensive set of multidisciplinary competencies. In accordance with the international declarations, one of the twenty-first century nursing practice directions are: assurance of health care quality and adequate use of technology; multiprofessional team work; autonomous nurses work in hospitals and communities. The context of good practice: nursing practice isn't focused on the execution of tasks, but to the patient is raised.

The intellectual, professional, academic and practical competencies that nursing graduates must acquire are informed by the European Tuning project (2009). The programme must also provide the programme hours specified in Directive 2013/55/EC and be at least equal to a first cycle (end of cycle) qualification of the European Higher Education Area (EHEA) (see Fig. 1).

Programmes should offer a flexible, blended approach to learning, and draw on the full range of modern learning methods and modes of delivery in both academic and practice settings. There are learning opportunities wherever nurses practise. Learning should be shared with other nursing students, and also 
with students from other disciplines to improve teamwork and service integration.

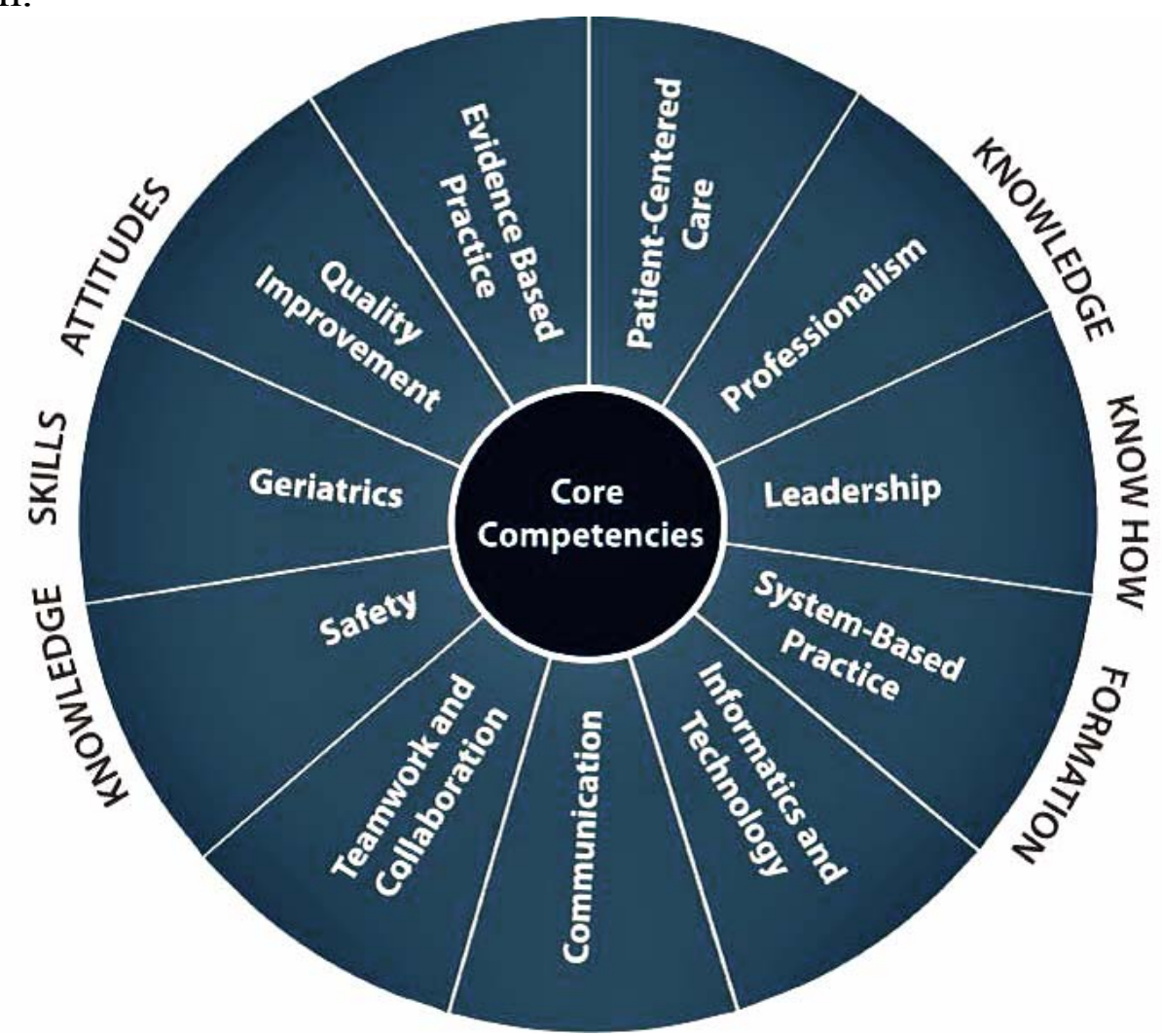

Figure 1. Nurse core competencies

(according by the Maine Nursing Core Competencies, 2013)

Students should become increasingly self-directed and independent, and able to make use of a variety of resources, because the future of nursing in today's world requires an examination of how we educate and what content we impart to nurses. Just as clinical practice needs to be grounded in evidence, effective nursing education is dependent upon the development and use of andragogic and pedagogic evidence. Educational research findings must be transformed into useable education strategies. There is a need for nursing education strategies that engage students in critical thinking while allowing practice in safe environments. However, opportunities to train for some healthrelated events are severely limited (Farraet al., 2015). For example, acute period of myocardial infarction, stroke, various operations and etc., but practice is needed to prepare a well-trained healthcare team to respond to these conditions.

Internationally, simulation is recognised as an innovative pedagogic approach that has gained much popularity and hence provides the focus for this special edition. Simulated practice learning has been used as an adjunct to clinical skills gained in practice settings for a number of years. Life size manikins were first used to support learning in 1911, becoming more popular in the 1950s. Today, simulation encompasses a range of delivery methods and modes including low-fidelity basic simulators such as a simulated wound site, high-fidelity interactive manikins with life-like qualities, role play, case studies 
and virtual online environments (Moule, 2011). The main incentive to establish medical simulation traininghas been to improve the quality of instruction in nursing as a step towards better qualityof healthcare and increased patient safety. The Circle of Learning (see Fig. 2) reflects the continuing process ofattaining, maintaining, and enhancing clinical competence (Thomseth, 2011).

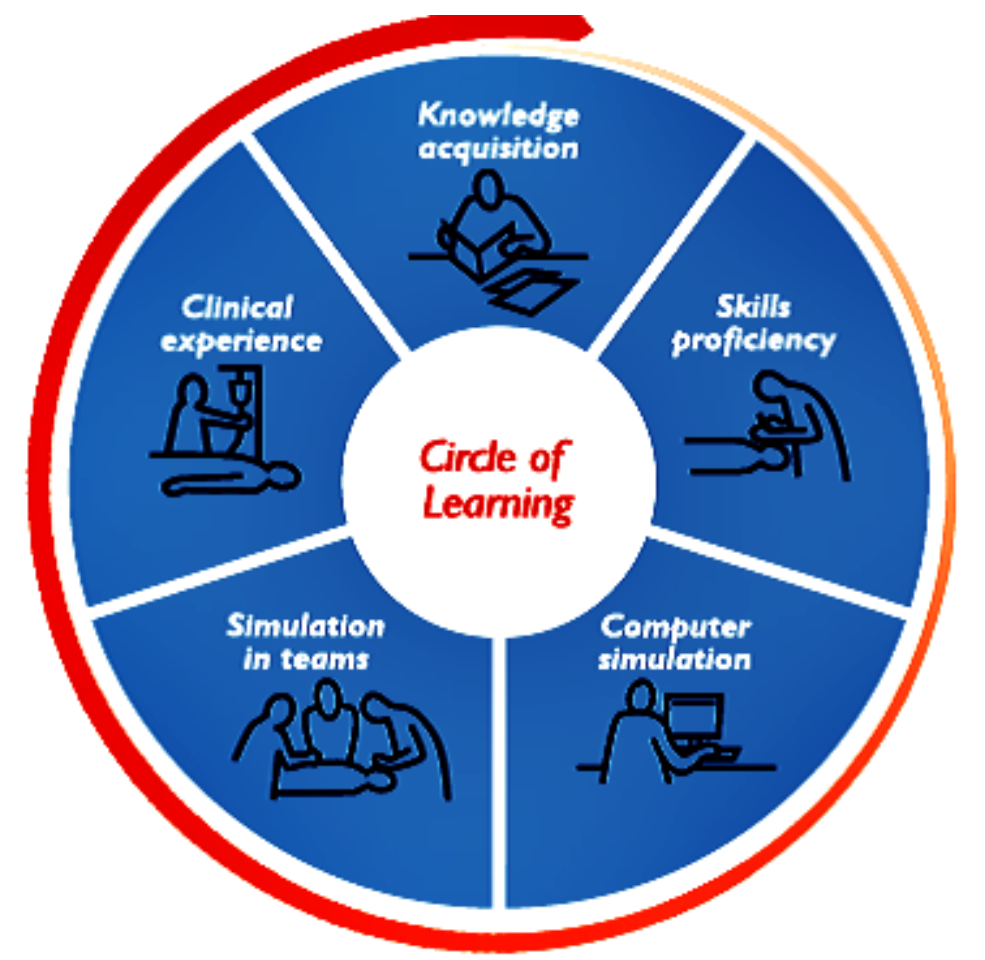

Figure 2. The Circle of learning reflects the continuing process of attaining, enhancing, and maintaining clinical competencies (according by Thomseth, 2011)

Students are exposed to a realistic situation that could be community or hospital based and will need to combine their assessment and clinical decisionmaking skills with communication, teamwork and management to care for the

simulated patient(s). Following the simulation, the learners are able to reflect on their performances with a facilitator. By discussing their areas of strength and development in line with current evidence, they can begin to improve their competence, and ultimately, confidence. This learning can be consolidated back into practice. Why simulation? Teaching using simulation needs to occur in a realistic environment so that when the learners return to the workplace, they can easily apply what is learned.

Second innovative teaching intervention is virtual reality simulation (VRS). Virtual Reality is a broad term encompassing a wide range of technology (Blade \& Padgett, 2002), which can vary from desktop computer simulations to head-mounted displays with sophisticated motion tracking to spatialized audio systems to multi-wall 3D projection systems. While the technology varies, the common theme of VRS is to provide a humane computer interface that simulates an alternate three-dimensional environment and presents multisensory 
stimulation to the user (e.g., some combination of visual, auditory, haptic, olfactory, proprioceptive, inertial, etc.) and allows the user to interact with thesynthetic environment in real time(Stanney \& Cohn, 2009; Stanney and Zyda, 2002). According to Farra et al. (2015), VRS refers to an interactive desktop computer simulation, which is preferred for itslow cost, wide accessibility and ability to embed such simulations with a website for distribution. The use of VRS as an education method is grounded by the theory of situated cognition. Learners must apply and practice inrealistic environments. In summary, the theory is based upon concepts of embeddedness (cognition is fixed in context specific representations), extension (cognitive systems exist in a physical and social environment) and embodiment (cognition is dependent on the sensorimotor brain and body).

Educational technology, through virtual reality and interactive multimedia, is supported as an avenue to bring situated learning into the classroom. The framework of situated cognition virtual simulations provides a learning opportunity that has the critical characteristics of a traditional apprenticeship. Interactivity is a key to learning. Moreover, situated cognition fosters the expansion of individual cognitive knowledge along with social and physical interactions thus facilitating cognitive, affective, and psychomotor learning (Farra et al. 2015).

It is claimed that the technology assisted learning (TAL) is increasingly becoming important for both formal and non-formal education. Perform research has compared different learning media and produced some evidence suggesting that TAL, if adequately designed and implemented, can generate learning outcomes comparable to or even better than those attainable by traditional, classroom-based learning. TAL teaching is said to provide a new paradigm for imparting knowledge, where by students are able to learn any time, even when they are at home. As a result, learners can progress on their own initiative to study the content of the course (Parai et al., 2015). In the study process numerous technological resources (database) and materials, such as e-books, videos, interactive animations and etc., are used by the nursing programme to enhance student learning. This is with the intention of helping the students understand the concepts better and clear, to make the method of delivery easy and interesting, and to facilitate easy access to education materials at the convenience of learner. Though incorporating TAL in the teaching - learning process may benefit in terms of easy delivery and easy access to information, it is questionable whether TAL guarantees knowledge gain. In addition, it is worth noting that learning engagement underscores the importance of participation in study and often has a positive association with emotional engagement, as signified by learning interest orsatisfaction. Therefore, student attitude and acceptance ofa training method are important precursors to the successof any educational method (Jwayyed et al., 2011). 
In summary, the application of the IT technology in the nursing training process facilitates learning, when training is conducted under the „rightconditions“. The right conditions include: feedback is provided during the learning experience, learners engage in repetitive practice, simulation is integrated into the normal training schedule, learners practice with increasing levels of difficulty, adaptable to multiple learning strategies, a wide variety of clinical conditions are provided, learning on the simulator occurs in a controlled

Environment, individualized learning and team learning are provided, learning outcomes are clearly defined, ensures the simulator is a valid learning tool.

\section{Empirical Research Material and Methods}

In research, realization has made the literature analysis and instantly quantitative and qualitative study was performed. Sample consisted of 318 respondents. 308 questionnaires filled in correctly were evaluated. The reversibility of the questionnaires was 77.18 per cent.

Respondents for the research were chosen from two educational institutions providing professional nursing and two health care institutions.

The research was conducted using the authors concluded Nurse clinical competence scale on the basis of Finland scientists MeretojaNursing competence scale (2003), with the written consent of the author.

Methods of research: closed questions - data analysis performed using: statistic analysis. All data was entered into a computer database and analyzed using SPSS thirteen-one. Significance was set at $\mathrm{P}<0.05$. Descriptive statistics were used, correlation (Spearman coefficient) and variance (ANOVAs test) analysis. Phenomenological qualitative content analysis was applied to the examination of additional content of the respondents. The data were analyzed by forming two respondents groups order to the accuracy. The first group: practicing and graduate, extended students were assigned for this group too. The second group was made of the second and third-year nurse students.

\section{Survey Results}

Advanced nursing practice describes the work or what nurses "do" in the role. There is no single definition, but agreement that advanced nursing practice extends the traditional scope of nursing, involves highly autonomous practice, maximizes the use of nursing knowledge, and contributes to the development of the profession (Byrant-Lukosiuset al., 2004). What's means nurse's clinical competence? It is the habitual capability and judicious use of communication, knowledge, technical skills, clinical reasoning, emotions, values, and reflection in daily practice for the benefit of the individual and community is being served.

Research results discovered that: 49, 35 per cent respondents to evaluate their competence as a very high (Fig. 3.). 


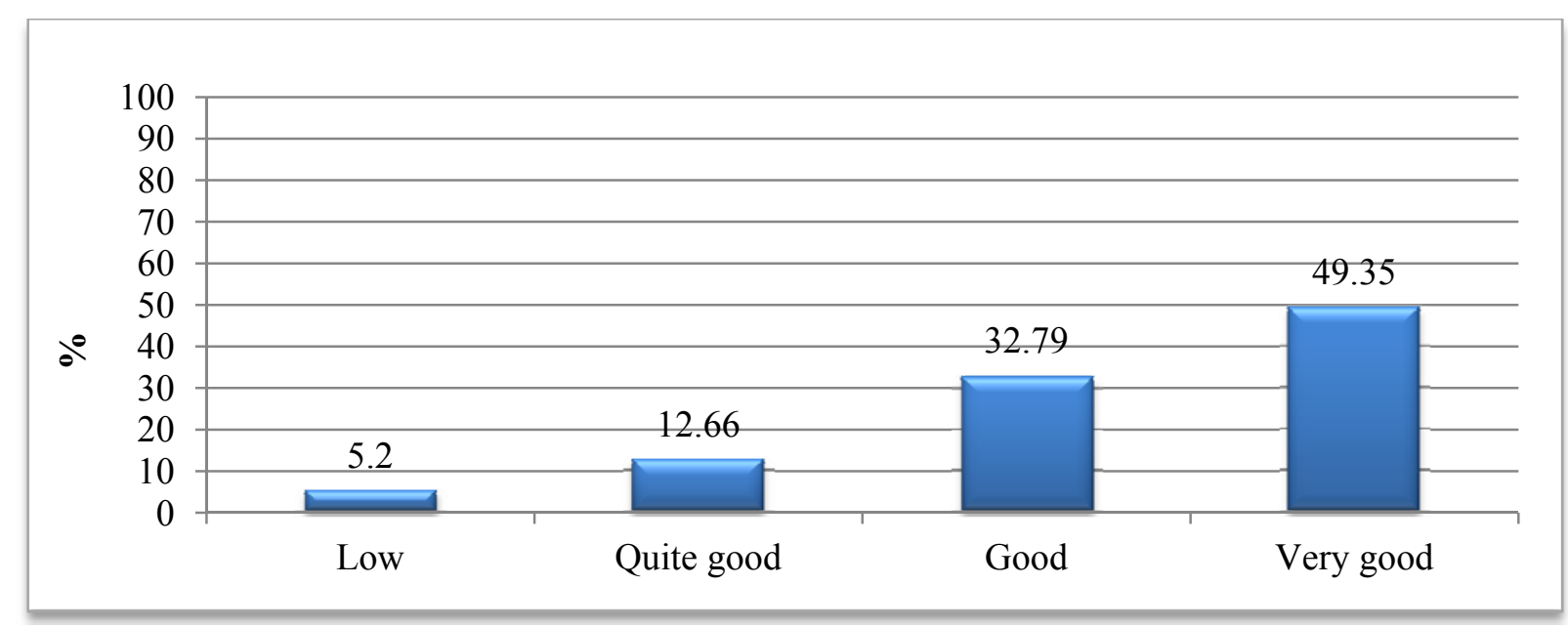

Figure 3. Level of Competence

In the figure 4 we can see that practicing nurse and graduate in most cases of them activities using utilizing information technology in them work (average grade - 2.4). Students will mainly use incorporating IT knowledge to provide optimal care (average grade - 0.77).

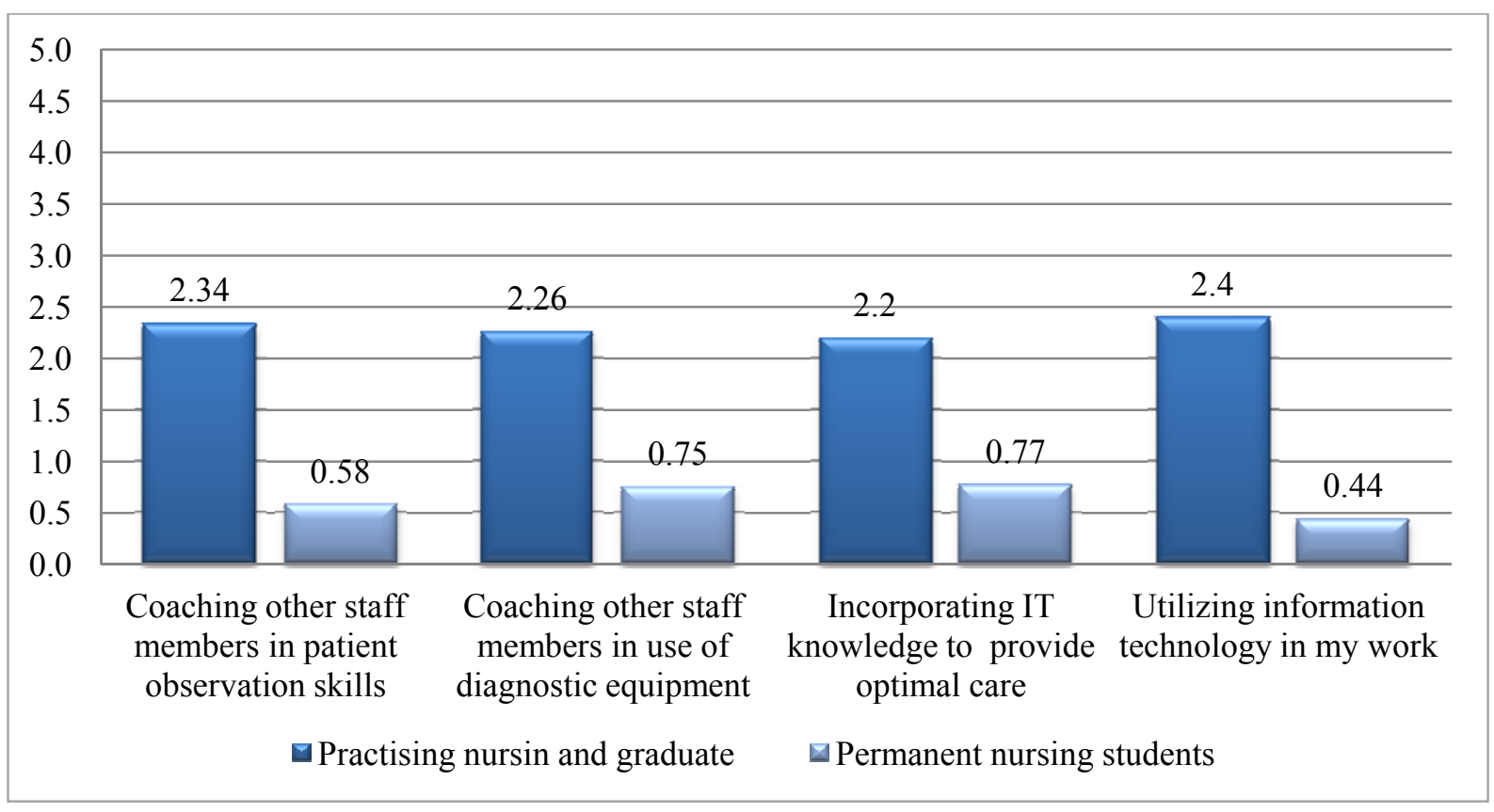

Figure 4. Assessment of IT competence elements by considering at the terms of rates (average grade)

Practising nursing and graduate which their level of competence to evaluate higher scoreo ften coaching other staff members in patient observation $\operatorname{skills}(\rho=0,2 ; \mathrm{p}=0,02)$. There was a significant relationship between the use of the competence element and the level of competence. By comparing the second and third-year nursing student answers, obtained results was confirmed the practical experience influence for use frequency of all IT competence' elements. Thirdyear nurse students more often use IT competencies in the practice (Table1). 
SOCIETY. INTEGRATION. EDUCATION. Volume IV

Table 1. Comparison of using IT competence' elements averages by the practical experience

\begin{tabular}{|c|c|c|c|c|c|c|c|c|c|}
\hline \multirow{4}{*}{ No } & \multirow{4}{*}{$\begin{array}{l}\text { Competence } \\
\text { element }\end{array}$} & \multicolumn{4}{|c|}{$\begin{array}{l}\mathrm{I}^{\text {st }} \text { group. Practising nursing and } \\
\text { graduate }\end{array}$} & \multirow{4}{*}{$F ; p$} & \multirow{2}{*}{\multicolumn{2}{|c|}{\begin{tabular}{|l} 
II ${ }^{\mathrm{nd}}$ group. \\
Students \\
Course
\end{tabular}}} & \multirow{4}{*}{$F ; p$} \\
\hline & & \multicolumn{3}{|c|}{ Level of Health Care } & \multirow[t]{2}{*}{ Graduate } & & & & \\
\hline & & $\mathrm{I}^{\mathrm{st}}$ & $\mathrm{II}^{\text {nd }}$ & $\mathrm{III}^{\mathrm{rd}}$ & & & II $^{\text {nd }}$ & $\mathrm{III}^{\mathrm{rd}}$ & \\
\hline & & $\begin{array}{l}\mathrm{M} \\
\text { (St.D) }\end{array}$ & $\begin{array}{l}\mathrm{M} \\
\text { (St.D) }\end{array}$ & $\begin{array}{l}\mathrm{M} \\
\text { (St.D) }\end{array}$ & M (St.D) & & $\begin{array}{l}\mathrm{M} \\
\text { (St.D) }\end{array}$ & $\begin{array}{l}\mathrm{M} \\
\text { (St.D) }\end{array}$ & \\
\hline 1 & 2 & 3 & 4 & 5 & 6 & 7 & 8 & 9 & 10 \\
\hline 1. & $\begin{array}{l}\text { Coaching other } \\
\text { staff members in } \\
\text { patient observation } \\
\text { skills }\end{array}$ & $\begin{array}{l}2,32 \\
(1,13)\end{array}$ & $\begin{array}{l}2,37 \\
(1,09)\end{array}$ & $\begin{array}{l}2,41 \\
(1,17)\end{array}$ & $\begin{array}{l}2,34 \\
(1,12)\end{array}$ & $\begin{array}{l}0,70 \\
0,59\end{array}$ & $\begin{array}{l}0,28 \\
(0,83)\end{array}$ & $\begin{array}{l}1,55 \\
(1,45)\end{array}$ & $\begin{array}{l}10,30 \\
0,00^{*}\end{array}$ \\
\hline 2. & $\begin{array}{l}\text { Coaching other } \\
\text { staff members in } \\
\text { use of diagnostic } \\
\text { equipment }\end{array}$ & $\begin{array}{l}2,32 \\
(1,11)\end{array}$ & $\begin{array}{l}2,30 \\
(1,13)\end{array}$ & $\begin{array}{l}2,68 \\
(0,97)\end{array}$ & $\begin{array}{l}2,26 \\
(1,18)\end{array}$ & $\begin{array}{l}0,67 \\
0,61\end{array}$ & $\begin{array}{l}0,43 \\
(0,78)\end{array}$ & $\begin{array}{l}1,68 \\
(1,47)\end{array}$ & $\begin{array}{l}11,34 \\
0,00^{*}\end{array}$ \\
\hline 3. & $\begin{array}{l}\text { Incorporating IT } \\
\text { knowledge to } \\
\text { provide optimal } \\
\text { care }\end{array}$ & $\begin{array}{l}2,23 \\
(1,11)\end{array}$ & $\begin{array}{l}2,22 \\
(1,05)\end{array}$ & $\begin{array}{l}2,16 \\
(1,24)\end{array}$ & $\begin{array}{l}2,20 \\
1,05)\end{array}$ & $\begin{array}{l}0,06 \\
0,99\end{array}$ & $\begin{array}{l}0,47 \\
(1,02)\end{array}$ & $\begin{array}{l}1,52 \\
(1,34)\end{array}$ & $\begin{array}{l}10,90 \\
0,00^{*}\end{array}$ \\
\hline 4. & $\begin{array}{l}\text { Utilizing } \\
\text { information } \\
\text { technology in my } \\
\text { work }\end{array}$ & $\begin{array}{l}2,58 \\
(1,07)\end{array}$ & $\begin{array}{l}2,44 \\
(1,06)\end{array}$ & $\begin{array}{l}2,38 \\
(1,26)\end{array}$ & $\begin{array}{l}2,40 \\
(1,11)\end{array}$ & $\begin{array}{l}0,59 \\
0,67\end{array}$ & $\begin{array}{l}0,28 \\
(0,77)\end{array}$ & $\begin{array}{l}1,4 \\
(1,43)\end{array}$ & $\begin{array}{l}4,34 \\
0,004 *\end{array}$ \\
\hline
\end{tabular}

*Statistically significant $F>1 ; p<0,05$ - significant, $p<0,01$ - very significant, $p<0,001$ particularlysignificant

The education has significant influence for three IT competences' elements in the first respondents group, while in the second group - than one (Table 2). It wasdetermined a particularly significant impact of the education to coaching other staff members in patient observation skills in the practicing nurses and graduates group $(F=8,996, p=0,00)$.

Table 2. Comparison of using IT competence' elements averages by the education

\begin{tabular}{|c|c|c|c|c|c|c|c|c|}
\hline \multirow{3}{*}{ No } & \multirow{3}{*}{$\begin{array}{l}\text { Competence } \\
\text { element }\end{array}$} & \multicolumn{4}{|c|}{$\begin{array}{l}\text { I }^{\text {st }} \text { group. Practising nursing and } \\
\text { graduate }\end{array}$} & \multicolumn{3}{|c|}{ II $^{\text {nd }}$ group. Students } \\
\hline & & $\begin{array}{l}\text { Medical } \\
\text { school }\end{array}$ & $\begin{array}{l}\text { Colle } \\
\text { ge }\end{array}$ & $\begin{array}{l}\text { Unive } \\
\text { rsity }\end{array}$ & \multirow{2}{*}{$\mathrm{F} ; \mathrm{p}$} & $\begin{array}{l}\text { Colle } \\
\text { ge }\end{array}$ & $\begin{array}{l}\text { Unive } \\
\text { rsity }\end{array}$ & \multirow{2}{*}{$F ; p$} \\
\hline & & $\begin{array}{l}\text { M } \\
\text { (St.D) }\end{array}$ & $\begin{array}{l}\text { M } \\
\text { (St.D) }\end{array}$ & $\begin{array}{l}\text { M } \\
\text { (St.D) }\end{array}$ & & $\begin{array}{l}\text { M } \\
\text { (St.D) }\end{array}$ & $\begin{array}{l}\text { M } \\
\text { (St.D) }\end{array}$ & \\
\hline 1 & 2 & 3 & 4 & 5 & 6 & 7 & 8 & 9 \\
\hline 1. & $\begin{array}{l}\text { Coaching other staff } \\
\text { members in patient } \\
\text { observation skills }\end{array}$ & $\begin{array}{l}2,37 \\
(1,09)\end{array}$ & $\begin{array}{l}2,39 \\
(1,07)\end{array}$ & $\begin{array}{l}2,34 \\
(1,12)\end{array}$ & $\begin{array}{l}8,99 \\
0,00^{*}\end{array}$ & $\begin{array}{l}0,42 \\
(0,99)\end{array}$ & $\begin{array}{l}0,7 \\
(1,21)\end{array}$ & $\begin{array}{l}0,40 \\
0,67\end{array}$ \\
\hline
\end{tabular}

Table 2 continued on next page 
Table 2 continued

\begin{tabular}{|l|l|l|l|l|l|l|l|l|}
\hline 1 & 2 & 3 & 4 & 5 & 6 & 7 & 8 & 9 \\
\hline 2. & $\begin{array}{l}\text { Coaching other staff } \\
\text { members in use of } \\
\text { diagnostic } \\
\text { equipment }\end{array}$ & 2,30 & 2,31 & 2,26 & 4,72 & 0,65 & 0,87 & 1,15 \\
$(1,13)$ & $(1,14)$ & $(1,18)$ & $0,001^{*}$ & $(1,28)$ & $(1,31)$ & 0,34 \\
\hline 3. & $\begin{array}{l}\text { Incorporating IT } \\
\text { knowledge to } \\
\text { provide optimal } \\
\text { care }\end{array}$ & $\begin{array}{l}2,22 \\
(1,05)\end{array}$ & $\begin{array}{l}2,23 \\
(1,05)\end{array}$ & $\begin{array}{l}2,20 \\
(1,05)\end{array}$ & $\begin{array}{l}1,29 \\
0,27\end{array}$ & $\begin{array}{l}0,71 \\
(1,19)\end{array}$ & $\begin{array}{l}0,83 \\
(1,32)\end{array}$ & 0,22 \\
0,93 \\
\hline 4. & $\begin{array}{l}\text { Utilizing } \\
\text { information in my } \\
\text { technology in } \\
\text { work }\end{array}$ & $\begin{array}{l}2,44 \\
(1,07)\end{array}$ & $\begin{array}{l}2,46 \\
(1,06)\end{array}$ & $\begin{array}{l}2,40 \\
(1,11)\end{array}$ & $\begin{array}{l}3,75 \\
0,01^{*}\end{array}$ & $\begin{array}{l}0,42 \\
(0,92)\end{array}$ & $\begin{array}{l}0,47 \\
(1,04)\end{array}$ & 0,99 \\
0,42 \\
\hline
\end{tabular}

* Statistically significant $p<0,05$ - significant, $p<0,01$ - very significant, $p<0,001$ particularly significant

The respondents identified the achievement of permanent knowledge, professional development by introducing innovations in the nursing in the field of the use of technologies. Both for the nurses' practitioners and students it is important: „advanced technology and the ability to use them, by ensuring the quality of nursing and reducing potential risk by providing services". The purpose of technology using in nursing are defined as: ,the ability of nursing staff to work with new diagnostic equipment and the ability to identify the patient's problems $<\ldots>$ to cooperate in the development and disseminating of data nursing research and improvements of the implementation of information technology $<\ldots>$ in the applications models of nursing and individual nursing“.

Revealed the following key sings of advanced nursing competence: experience and cleverness, analysis and assessment of care, training, and leadership, and the need of new modern technology competence.

In summary, the necessary points in all areas as in deployment technology assisted learning in study process, as in expanding the use of IT in the practice.

\section{Conclusions}

1. Modernization of nursing education based on inclusion of IT into the study process creates conditions for health educators provide more exemplars of how research evidence can be moved through the various stages of the model to advance practice and sustain learning outcomes.

2. Comparing rate of use of nursing IT competence elements in the practice regarding to the factors which determinate competence, was appointed that in the practice of group of practicing nurses and graduates the level of competence impact has with one element and impact of education for three elements. For the students' statistical meaningful and reliable impact of practical activities was appointed for all four elements. 


\section{SOCIETY. INTEGRATION. EDUCATION. Volume IV}

3. Main features of advanced nursing clinical competence are: experience and cleverness, monitoring and evaluation of care training and leadership and needs of new competency of modern technology. The advanced technology and the ability to use them, by ensuring the quality of nursing and reducing potential risk by providing services is important for the nurses practitioners and students.

\section{References}

Bielinienė N. (2007). Slaugytoju kompetencijos kaitos tendencijos visuomenés poreikiu raidos kontekste: magistro darbas: socialiniai mokslai, edukologija (07S). Vilniaus pedagoginis universitetas. Vilnius.

Byrant-Lukosius, D., Dikenso, A., Browne, G., Pirelli, J. (2004). Advanced practice-nursing roles: development, implementation and evaluation. Journal of Advanced Nursing, 48(5), $519-529$.

Blade R. A., Padgett M. L. (2002). Virtual environments standards and terminology. In: Stanney's, K.M. (Ed.), Handbook of Virtual Environments: Design Implementation, and Applications. Lawrence Erlbaum Associates, Mahwah, New Jersey, 15-27.

Brief History of Nursing Informatics in Canada. Avialable from: http://www.nursinginformatics.com/kwantlen/history.html.

Farra S. L., Miller E. T., Hodgson E. (2015). Virtual reality disaster training: Translation to practice. Nurse Education in Practice, 15, 53-57.

Jwayyed S., Stiffler K. A., Wilber S. T., Southern A., Weigand J., Bare R. et al. (2011). Technology-assisted education in graduate medical education: A review of the literature. International Journal of Emergency Medicine, 4, 51.

Maine Nurse Core Competencies (2013). Available from: $<\mathrm{http}: / /$ www.mainenursepartners.com $>$.

Meretoja R. (2003). Nurse Competence Scale. Academic Dissertation. University of Turku, Ser. D 578.

Moule P. (2011). Simulation in nurse education: past, present and future. Journal of Nurse Education Today, 31, 645-646.

Paraia M., Shenoya P, Loh K.Y. (2015). Students' perception of technology-assisted learning in undergraduate medical education - A survey. The Social Science Journal, 52, 78-82.

Stanney K.M., Zyda M. (2002). Virtual environments in the 21st century. In: Stanney's, K.M. (Ed.), Handbook of Virtual Environments: Design Implementation, and Applications. Lawrence Erlbaum Associates, Mahwah, New Jersey, 1-14.

Stanney K., Cohn J. (2009). Virtual environments. In: Jacko's, J.A. (Ed.), Humane computer Interaction: Design Issues, Solutions, and Applications, 293-310.

Ševcovienè D. (2010). Pažangios slaugos praktikos klinikinès kompetencijos vertinimas, slaugos mokslai (11B). Kauno medicinos universitetas, Kaunas.

Thomseth E. (2011). Case study. Simuliation in Nursing Education. Downloaded from http://www.laerdal.com

Žydžiūnaitè V. (2002). Slaugytojų kompetencijų charakteristikos: edukologijos ir slaugos požiūriai. Sveikatos mokslai, 4(20):53 - 59. 